\title{
Phytoremediation of Contaminated Soils from Challawa Industrial Estate, Kano-Nigeria
}

\author{
U. Abdullahi, ", A. A. Audu ${ }^{1}$, Kalimullah ${ }^{2}$, L. Shuaibu ${ }^{3}$ \\ ${ }^{1}$ Department of Pure and Industrial Chemistry, Faculty of Natural and Applied Sciences, Umaru Musa Yar'Adua University, Katsina-Nigeria \\ ${ }^{2}$ Department of Biological Sciences, Faculty of Natural and Applied Sciences, Umaru Musa Yar'Adua University, Katsina-Nigeria \\ ${ }^{3}$ Department of Pure and Industrial Chemistry, Faculty of Science, Federal University Birnin Kebbi, Kebbi-Nigeria
}

\section{Email address:}

ussydaddy@gmail.com (U. Abdullahi)

${ }^{*}$ Corresponding author

\section{To cite this article:}

U. Abdullahi, A. A. Audu, Kalimullah, L. Shuaibu. Phytoremediation of Contaminated Soils from Challawa Industrial Estate, Kano-Nigeria. Science Journal of Analytical Chemistry. Vol. 4, No. 5, 2016, pp. 59-65. doi: 10.11648/j.sjac.20160405.11

Received: August 22, 2016; Accepted: September 5, 2016; Published: September 22, 2016

\begin{abstract}
Field studies to examine the phytoremediation potential of some plants for metals $(\mathrm{Cd}, \mathrm{Cr}, \mathrm{Cu}, \mathrm{Fe}, \mathrm{Mn}, \mathrm{Ni}, \mathrm{Pb}$ and $\mathrm{Zn}$ ) in metals contaminated soils of Challawa industrial estate, Kano has been carried out. A total of one hundred and eighty (180) samples comprising of 80 (soils), 20 (effluents), and 80 (plant parts) of Jatropha (Jatropha curcas), Neem (Azadirachta indica) and Baobab (Adansonia digitata) were analyzed. $0.50 \mathrm{~g}$ of the plant tissue and $1.0 \mathrm{~g}$ of soil sample and $50 \mathrm{~mL}$ of the effluent sample were digested using triacid digestion method and the levels of the metals were determined by the use of atomic absorption spectrophotometry. The mean levels of the metals in plants and soils from contaminated and control sites were found to be in the sequence of $\mathrm{Fe}(406.27 \pm 45.93)>\mathrm{Zn}(137.20 \pm 8.00)>\mathrm{Cu}(118.60 \pm 0.00)>\mathrm{Cd}(62.57 \pm 6.86)>\mathrm{Mn}(21.53 \pm 1.79)>\mathrm{Ni}(14.36 \pm 2.22)>$ $\mathrm{Cr}(13.73 \pm 1.79)>\mathrm{Pb}(12.80 \pm 0.00)$ and $\mathrm{Fe}(130.23 \pm 18.01)>\mathrm{Zn}(65.36 \pm 4.90)>\mathrm{Cu}(26.22 \pm 5.50)>\mathrm{Cd}(23.08 \pm 2.43)>\mathrm{Ni}$ $(5.70 \pm 0.00)>\mathrm{Mn}(4.86 \pm 2.21)>\mathrm{Cr}(4.80 \pm 2.10)>\mathrm{Pb}(3.03 \pm 1.50)$ respectively. The contamination factor $(\mathrm{CF})$ of all the metals in the plants were found to be in the sequence of $\mathrm{Cd}(8.45 \pm 1.42)>\mathrm{Cu}(2.52 \pm 1.00)>\mathrm{Cr}(2.28 \pm 0.00)>\mathrm{Zn}(1.80 \pm 1.19)>\mathrm{Fe}(1.56 \pm 0.00)>$ $\mathrm{Pb}(1.49 \pm 0.11)>\mathrm{Mn}(1.09 \pm 0.18)>\mathrm{Ni}(1.00 \pm 0.06)$. The results showed that these plants can be used for the phytoextraction of the metals from contaminated soils. The values of bioaccumulation and translocation factors were also found to be more than one in almost all cases. From these results it could be recommended that the three plants investigated would be ideal for phytoremediation in multi-metal contaminated soils.
\end{abstract}

Keywords: Phytoremediation, Contamination Factor, Bioaccumulation Factor, Translocation Factor, Heavy Metals, Contaminated Soils

\section{Introduction}

Plant based bioremediation technologies have been collectively termed as phytoremediation, referring to the use of green plants and associated micro biota for the in-situ treatment of contaminated soil and ground water [1]. The idea of using metal accumulating plants to remove heavy metals and other compounds was firstly introduced more than 310 years ago [2]. Phytoremediation is an environmentally friendly, safe and cheap technique to remove the pollutants from the environment. Phytoremediation as a technology uses plants to clean up contaminated environment. It is a low cost, long term, environmentally and aesthetically friendly method of immobilizing/stabilizing, degrading, transferring, removing, or detoxifying contaminants, including metals, pesticides, hydrocarbons and chlorinated solvents $[3,4,5]$.

Over the past three decades, it has become a highly accepted means of detoxifying contaminated water and soils [6].The development of phytoremediation is being driven primarily by the high cost of many other soil remediation methods as well as a desire to use a "green", sustainable process. Metals contaminated soils are remediated by conventional or unconventional techniques but the in-situ (unconventional) techniques are favored over the ex-situ (conventional) techniques due to their low cost and reduced impact on the ecosystem. Conventionally, the ex-situ 
technique is to excavate soils contaminated with heavy metals and their burial in landfill sites [7, 8]. The offsite burial is not an appropriate option as it merely shifts the contamination problem elsewhere [8] and also because of the hazard associated with the transportation of contaminated soils [9]. Most of the conventional remediation technologies are costly to implement and cause further disturbances to the already damaged environment $[10,11]$. Basically, phytoremediation of contaminants is categorized under five major sub-groups: phytoextraction, phytostabilisation, phytofiltration, phytovolatilization and phytodegradation [12, 13]. The effluents from the industries in the estate were connected by a canal and channeled directly into the river. The increasing discharge of industrial wastes into this river is posing serious danger to the soils, water resources and the health of people in the area [14]. The major problem facing the city is the management of the wastewater discharged from the Challawa industrial estate and other industries located within the state. Effluents from Challawa industrial estate have been assessed and found that the level of $\mathrm{Cr}, \mathrm{Zn}, \mathrm{SO}_{4}{ }^{2-}, \mathrm{NO}_{3}{ }^{-}$and $\mathrm{DO}$ were above the FEPA and WHO maximum limits $[15,16]$. Also the physico-chemical pollutant indicators from textiles and tanneries in Challawa industrial area were assessed and it was noted that higher levels of $\mathrm{pH}$, temperature, conductivity, turbidity and color, TSS, oil and grease exist above WHO standard limit [17]. Mu'azu el al. [18] had reported that the concentrations of $\mathrm{Cu}, \mathrm{Zn}, \mathrm{Mn}, \mathrm{Pb}, \mathrm{Cr}$ and $\mathrm{Ni}$ were significantly higher than the levels recommended by Food and Agriculture Organization (FAO), Federal Environmental Protection Agency (FEPA) and the WHO/EU joint limits. This study was aimed at examining the phytoremediation potentials of Jatropha (Jatropha curcas), Neem (Azadirachta indica) and Baobab (Adansonia digitata) on contaminated soils, by assessing the ability of the plants to clean up environment. The Contamination factor $\left(\mathrm{C}_{\mathrm{f}}\right)$ is used to determine the contamination status of soil and is expressed in terms of contamination factor $\left(\mathrm{C}_{\mathrm{f}}\right)$ calculated using the relation described [19]. Four contamination categories are recognized on the basis of the contamination factor $\left(\mathrm{C}_{\mathrm{f}}\right)$ and its interpretation is as follows: $\mathrm{C}_{\mathrm{f}}<1$ means low contamination; 1 $<\mathrm{C}_{\mathrm{f}}<3$ means moderate contamination; $3<\mathrm{C}_{\mathrm{f}}<6$ means considerable contamination; $\mathrm{C}_{\mathrm{f}}>6$ means very high contamination [20]. The bioaccumulation factor (BAF) represents the contaminant concentration in plants comparing with the environment concentration in soil [21-22]. Bioaccumulation Coefficient (BAC) was determined to quantify the heavy metal accumulation efficiency in plants by comparing the concentration in the plant parts (roots, stems and leaves) and on external medium such as the soil or water [23]. This gives the metal level per plant organ which is a better estimate of heavy metal extraction efficiency in a given plant species [24].

The Translocation factors $(\mathrm{TF})$ is defined as the ratio of metal concentration in the shoots to those in the roots. $\mathrm{TF}=[\mathrm{Ts}] /[\mathrm{Tr}]$, where $\mathrm{Ts}$ and $\mathrm{Tr}$ are the concentration $(\mathrm{mg} / \mathrm{kg})$ accumulated in the shoots and roots respectively. TF $>1$ indicates that the plants translocate metals effectively from the roots to the shoots [21].

The bioaccumulation factor (BAF) is defined as the ratio of metal concentration in the roots to those in the soil or water, and is determined using $\mathrm{BAF}=\left[\mathrm{C}_{\text {plants }}\right] /\left[\mathrm{C}_{\text {environment }}\right]$. Where $\mathrm{C}_{\text {plants }}$ and $\mathrm{C}_{\text {environment }}$ are concentration $(\mathrm{mg} / \mathrm{kg})$ in the plant and in the environment (soil or water) while $\mathrm{BAF}>1$ indicates that the plant is a metal accumulator [21].

\section{Material and Methods}

\subsection{Study Area}

Challawa industrial estate is located in Kumbotso Local Government Area of Kano State. It is located in the northern Nigeria covering an area extending between latitude $12^{\circ} 40^{\prime}$ and $10^{\circ} 30^{\prime}$ and longitude $7^{\circ} 40^{\prime}$ and $90^{\circ} 40^{\prime}$ (Figure 1). The industries in the Challawa industrial estate range from tanneries and textiles to food and packaging / processing.

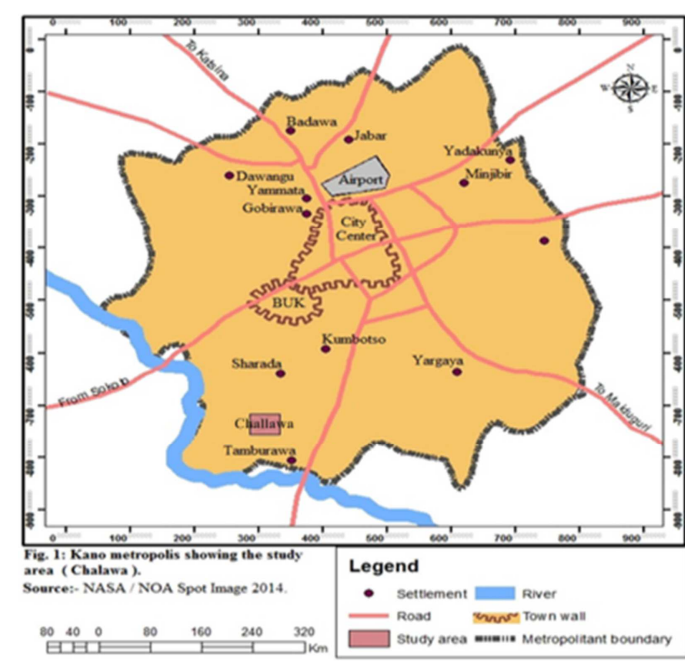

Figure 1. Map of Kano Metropolis Showing the Study Area (Challawa).

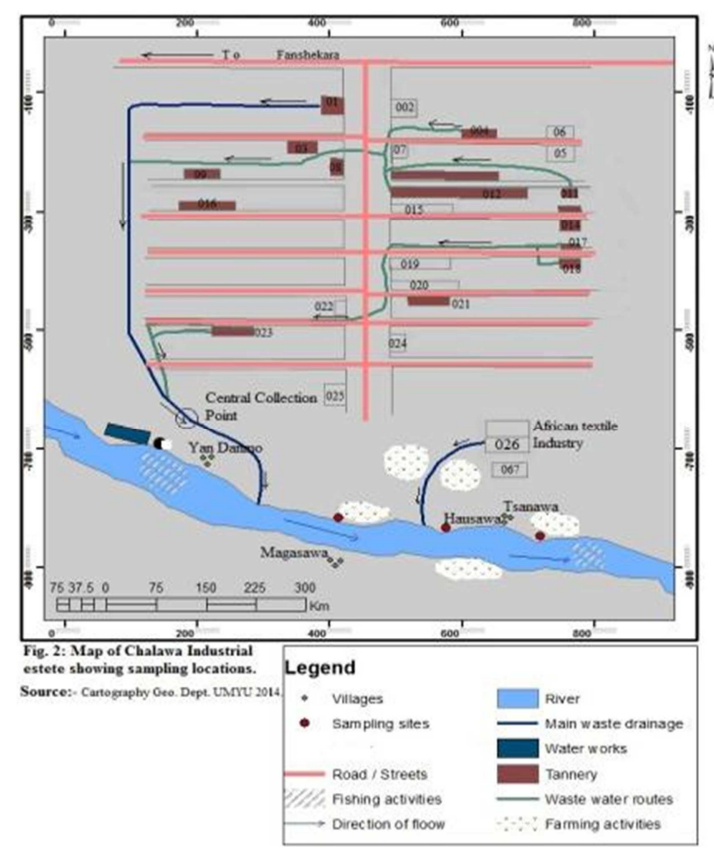

Figure 2. Map of Challawa industrial estate showing the sampling sites. 


\subsection{Cleaning of Glass Wares}

Glass wares, plastic containers, crucibles, pestle and mortar were washed with liquid detergent, rinsed with distilled deionized water and then soaked in $10 \% \mathrm{HNO}_{3}$ solution for 24 hours [25]. They were then washed with distilled water and dried in an oven at $80^{\circ} \mathrm{C}$ for 3 hours. Other chemicals and reagents used in this study were of analytical grade obtained from BDH and Sigma-Aldrich. Distilled water was also used for dissolution of metals salts used in the analysis. Procedural and reagent blanks were used and a clean laboratory environment was ensured during the analysis and preparation of solutions. The Atomic Absorption Spectrophotometer (Buck Scientific AAS Model 210VGP) was calibrated with multi-element standard solution (MESS) and the calibration standards were analyzed after 10 sample runs to ensure that the instrument remained calibrated [26].

\subsection{Samples Collection}

A total of one hundred and eighty (180) samples comprising of eighty (80) soils, twenty (20) of effluents and eighty (80) of leaves, stems and roots of Jatropha (Jatropha curcas), Neem (Azadirachta indica) and Baobab (Adansonia digitata) were collected from the sites and transported to the laboratory. The control samples were collected at Barhin village which is $50 \mathrm{~km}$ off Mani - Katsina Road. The samples were air-dried separately at room temperature in the laboratory.

\subsection{Samples Preparation}

The plant samples were separated into portions of roots, stems and leaves and then cut into small pieces and washed with tap water and then rinsed with distilled deionized water. These were placed on card board papers and dried in an open-air in the laboratory for three weeks. The dried samples were ground into fine powder using ceramic pestle and mortar and stored in labeled stoppered plastic bottles. Soil samples were air-dried, ground to fine powder, sieved using a 10 mesh nylon sieve and stored in labeled polythene bags.

\subsection{Soil pH Determination}

The $\mathrm{pH}$ of the soil samples were measured using a calibrated SB20 $\mathrm{pH}$ meter. The calibration of the $\mathrm{pH}$ meter was carried out using two buffer solutions of $\mathrm{pH} 4$ and 10. 20 $\mathrm{mL}$ distilled deionized water was added to $15 \mathrm{~g}$ of the soil sample and allowed to stand for 5 minutes. The mixture was stirred vigorously and allowed to stand for another 3 minutes, with occasional stirring. The electrode of the $\mathrm{pH}$ meter was inserted into the swirled slurry and three replicate readings taken for each sample [27].

\subsection{Sample Digestion}

The water samples were digested according to procedure described by APHA [28]; in which $50 \mathrm{~mL}$ was first treated with $20 \mathrm{~mL}$ concentrated $\mathrm{HNO}_{3}$ and the mixture was heated on a hot plate until it is boiled. The heating was continued until white fumes from the solution appeared. It was allowed to cool, filtered using Whatman No. 42 filter paper into $100 \mathrm{~mL}$ standard volumetric flask and made up to the mark with distilled water.

The plant samples were digested according to procedure adopted by Awofolu [29]; whereby $0.5 \mathrm{~g}$ of the powdered sample was weighed into a $100 \mathrm{~mL}$ beaker and $5 \mathrm{~mL}$ of concentrated $\mathrm{HNO}_{3}$ and $2 \mathrm{~mL} \mathrm{HClO}_{4}$ were added. The mixture was then heated on hot plate at $95^{\circ} \mathrm{C}$ until the solution became clear. It was then filtered into a $100 \mathrm{~mL}$ volumetric flask and made up to the mark with distilled water.

The soil samples were digested using USEPA method 3050 [30]; whereby $1 \mathrm{~g}$ portion of soil sample was placed into a 100 $\mathrm{mL}$ beaker, followed by addition of $10 \mathrm{~mL}$ of $1: 1 \mathrm{HNO}_{3}: \mathrm{H}_{2} \mathrm{O}$. The mixture was then heated on hot plate at $105^{\circ} \mathrm{C}$ for 1 hour and allowed to cool to room temperature. This was followed by sequential addition of $5 \mathrm{~mL}$ of concentrated $\mathrm{HNO}_{3}, 1 \mathrm{~mL}$ of $\mathrm{H}_{2} \mathrm{O}_{2}$ and $5 \mathrm{~mL}$ of $\mathrm{HCl}$. The resulting solution was filtered and diluted with distilled deionized water to a final volume of 100 $\mathrm{mL}$ in volumetric flask.

\subsection{Atomic Absorption Spectrophotometer Analysis}

The concentration of heavy metals in the samples were determined using Atomic Absorption Spectrophotometer (Buck 210 VGP Model) equipped with a digital read-out system. Working standards were used, after serial dilution of 1000 ppm metal stock solution in each case. Calibration curves were generated by plotting absorbance values versus concentrations. By interpolation, the concentrations of the metals in sample digests were determined as described by Audu and Lawal [31].

\subsection{Statistical Analysis of Data}

Analysis of variance for the heavy metals concentrations (in soil and plants parts) were computed by the Duncan's multiple range test DMRT method [32]. The statistical variations were considered significant at $\mathrm{p}<0.05$. Comparison using t-test was also done to detect any significant differences in metal concentrations between plants from polluted and unpolluted site (Control).

\section{Results and Discussion}

The mean levels of heavy metals $(\mathrm{mg} / \mathrm{kg})$ in contaminated soils were significantly $(\mathrm{p}<0.05)$ higher compared with those from the uncontaminated site (Control) as shown in Table 1.

Table 1. Table showing the mean levels of heavy metals $(\mathrm{mg} / \mathrm{kg})$ in the Soils samples analyses in comparison to the maximum allowed Concentrations.

\begin{tabular}{llll}
\hline Metals & Contaminated soils $(M e a n \pm$ SD) & Uncontaminated soils(Control) (Mean \pm SD) & MAC Values in soils \\
\hline $\mathrm{Cd}$ & $23.08 \pm 9.83$ & $2.73 \pm 0.08$ & $0.03-0.30^{\mathrm{a}}$ \\
$\mathrm{Cr}$ & $4.80 \pm 1.17$ & $2.11 \pm 1.85$ & $5.00^{\mathrm{a}}$ \\
$\mathrm{Cu}$ & $26.22 \pm 4.17$ & $10.40 \pm 2.70$ & $5.00-20.00^{\mathrm{a}}$ \\
$\mathrm{Fe}$ & $130.23 \pm 31.25$ & $87.67 \pm 32.77$ & $3000-5000^{\mathrm{b}}$ \\
\hline
\end{tabular}




\begin{tabular}{llll}
\hline Metals & Contaminated soils (Mean \pm SD) & Uncontaminated soils(Control) (Mean \pm SD) & MAC Values in soils \\
\hline $\mathrm{Mn}$ & $4.86 \pm 1.68$ & $4.45 \pm 2.04$ & $40.00-900^{\mathrm{c}}$ \\
$\mathrm{Ni}$ & $5.70 \pm 0.70$ & $5.60 \pm 2.15$ & $2.00-7.50^{\mathrm{a}}$ \\
$\mathrm{Pb}$ & $3.03 \pm 0.44$ & $2.02 \pm 0.62$ & $2.00-20.00^{\mathrm{a}}$ \\
$\mathrm{Zn}$ & $65.36 \pm 10.68$ & $36.23 \pm 4.63$ & $1.00-900^{\mathrm{a}}$ \\
$\mathrm{pH}$ range & $5.37-5.56$ & $7.12-8.04$ & $6.79-7.13^{\mathrm{a}}$ \\
\hline
\end{tabular}

Key: MAC=Maximum Allowable Concentration; Source: a=Bowen (1979) [33], b= Awokunmi et al. (2010) [34], c=ATSDR (2000) [35].

The results in Table 1 showed that the soils in Challawa industrial estate are contaminated with metals $(\mathrm{Cd}, \mathrm{Cr}, \mathrm{Cu}, \mathrm{Fe}$, $\mathrm{Mn}, \mathrm{Ni}, \mathrm{Pb}$ and $\mathrm{Zn}$ ) and their $\mathrm{pH}$ was slightly acidic. Lower $\mathrm{pH}$ values in soil lead to higher heavy metal solubility [36].

The figures $(3-10)$ comparing the contents of each metal distribution in the tissues of the plants species in the polluted and unpolluted sites, showed that the plant species accumulated high concentrations of $\mathrm{Cd}, \mathrm{Cr}, \mathrm{Cu}, \mathrm{Fe}, \mathrm{Pb}$ and $\mathrm{Zn}$ in their tissues in polluted sites while high concentrations of $\mathrm{Mn}$ and $\mathrm{Ni}$ were accumulated by the plants species in unpolluted site. High metal accumulation in plant parts above normal limit indicates their tolerance to the heavy metal pollution in soil.

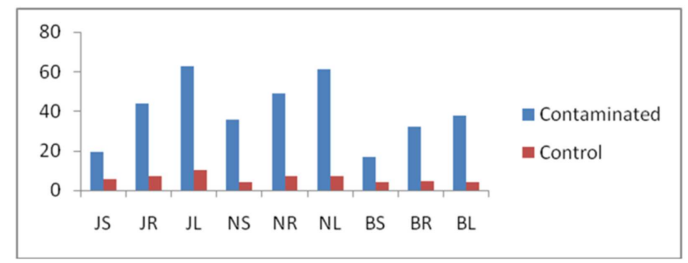

Figure 3. Showing the distribution of $\mathrm{Cd}$ metal in plants tissues in polluted and Non-polluted sites.

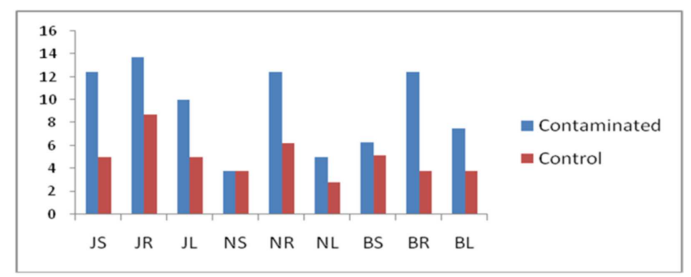

Figure 4. Showing the distribution of $\mathrm{Cr}$ metal in plants tissues in polluted and Non-polluted sites.

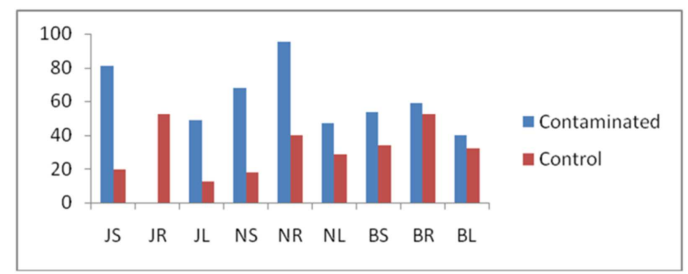

Figure 5. Showing the distribution of $\mathrm{Cu}$ metal in plants tissues in polluted and Non-polluted sites.

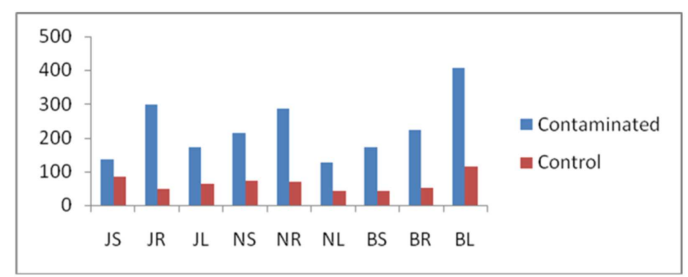

Figure 6. Showing the distribution of Fe metal in plants tissues in polluted and Non-polluted sites.

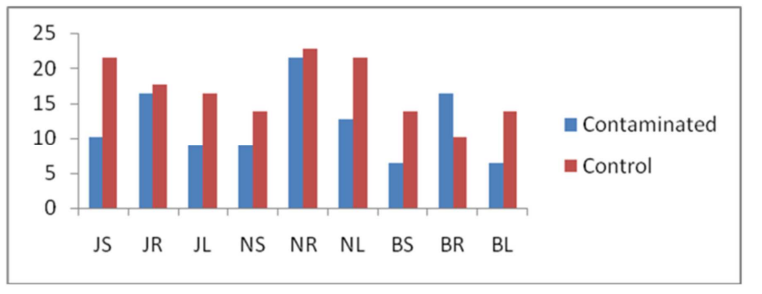

Figure 7. Showing the distribution of Mn metal in plants tissues in polluted and Non-polluted sites.

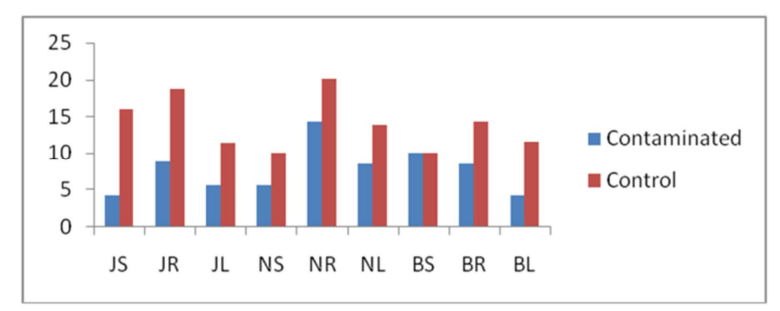

Figure 8. Showing the distribution of Ni metal in plants tissues in polluted and Non-polluted sites.

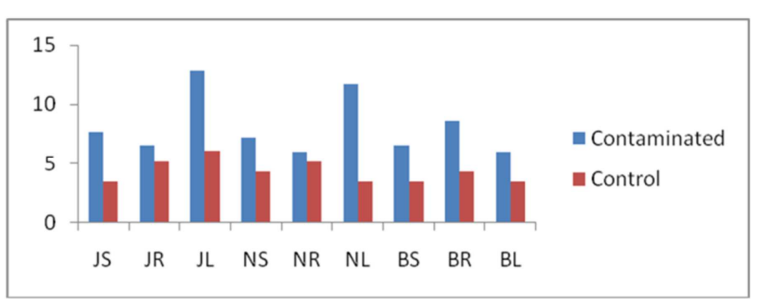

Figure 9. Showing the distribution of $\mathrm{Pb}$ metal in plants tissues in polluted and Non-polluted sites.

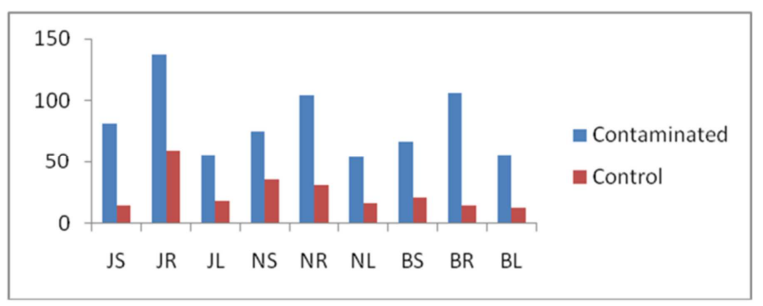

Figure 10. Showing the distribution of Zn metal in plants tissues in polluted and Non-polluted sites.

Key: JS=Jatropha Stems, JR= Jatropha Roots, JL= Jatropha Leaves, $\mathrm{NS}=$ Neem Stems, $\mathrm{NR}=$ Neem Roots, $\mathrm{NL}=$ Neem leaves, $\mathrm{BS}=$ Baobab Stems, $\mathrm{BR}=$ Baobab Roots and $\mathrm{BL}=$ Baobab Leaves.

The roots of Jatropha curcas accumulated high levels of the metals $(\mathrm{Cr}, \mathrm{Cu}, \mathrm{Fe}, \mathrm{Mn}$ and $\mathrm{Zn})$ while the leaves accumulated high levels of $\mathrm{Cd}, \mathrm{Ni}$ and $\mathrm{Pb}$ (Figure 11). This is in agreement with the findings of Qihang et al. [37] and Islam et al. [38] for the same plant. Thus, Jatropha curcas can be an ideal option for phytoremediation in multi-metal contaminated sites. The uptake of metals in the plant tissues indicates that the soluble 
metals can enter into the root cytoplasm by crossing the plasma membrane of the root of the endodermal cells [38]. The roots of Neem (Azadirachta indica) accumulated high levels of all the heavy metals: $\mathrm{Cd}, \mathrm{Cr}, \mathrm{Cu}, \mathrm{Fe}, \mathrm{Mn}, \mathrm{Ni}, \mathrm{Pb}$ and $\mathrm{Zn}$ (Figure 12), indicating that it has great potentials for phytoextraction of these metals from contaminated soil. Similarly, Baobab (Adansonia digitata) roots accumulated metals: $\mathrm{Cd}, \mathrm{Cr}, \mathrm{Cu}, \mathrm{Fe}, \mathrm{Mn}, \mathrm{Ni}, \mathrm{Pb}$ and $\mathrm{Zn}$ (Figure 13) which is consistent with observations of Barman et al. [39] and Malik et al. [36]. The highest concentration of $\mathrm{Cd}$ was accumulated by the leaves of all the three plant species and is similar to the report of Sun et al. [40]. Cadmium is one of the more mobile heavy metals in the soil-plant system, easily taken up by plants and with no essential function known to date [41]. As for the accumulation strategy, plants accumulate high amounts of $\mathrm{Cd}$ in their tissues, with only a small amount of $\mathrm{Cd}$ is stored in the roots and the rest translocated to the shoot.

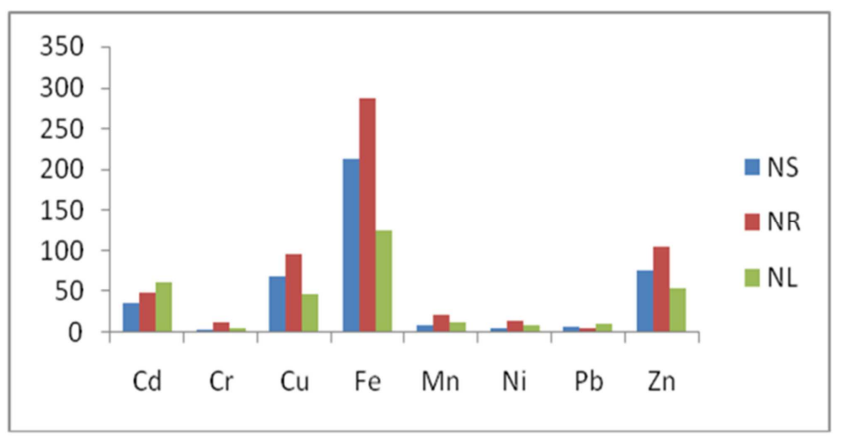

Figure 11. Showing the distribution of metals $(\mathrm{mg} / \mathrm{kg})$ in the stems, roots and leaves of Jatropha (Jatropha curcas) in the polluted area.

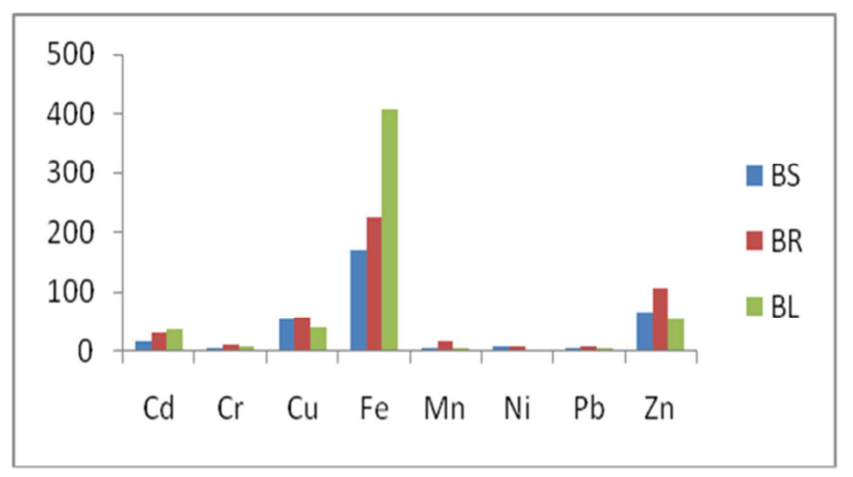

Figure 12. Showing the distribution of metals $(\mathrm{mg} / \mathrm{kg})$ in the stems, roots and leaves of Neem (Azadirachta indica) in the polluted area.

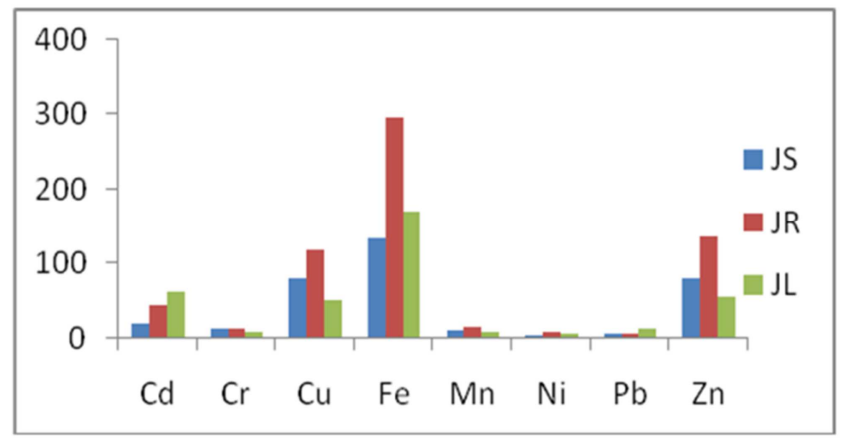

Figure 13. Showing the distribution of metals $(\mathrm{mg} / \mathrm{kg})$ in the stems, roots and leaves of Baobab (Adansonia digitata) in the polluted area.

Key: JS=Jatropha Stems, JR= Jatropha Roots, JL= Jatropha Leaves, $\mathrm{NS}=$ Neem Stems, $\mathrm{NR}=$ Neem Roots, $\mathrm{NL}=$ Neem leaves, $\mathrm{BS}=$ Baobab Stems, $\mathrm{BR}=$ Baobab Roots and $\mathrm{BL}=$ Baobab Leaves.

The contamination factor $\left(\mathrm{C}_{\mathrm{f}}\right)$ values revealed that the soils are highly contaminated with $\mathrm{Cd}(8.45 \pm 1.42)$ and $\mathrm{Cu}, \mathrm{Cr}, \mathrm{Zn}$ and $\mathrm{Fe}$ are said to have considerably contaminated the soils. $\mathrm{Pb}, \mathrm{Mn}$ and $\mathrm{Ni}$ are considered to have only moderately contaminated the soils (Table 2).

Table 2. Variation of Contamination Factor Values $(C F)(\mathrm{mg} / \mathrm{kg})$ with Soil Samples.

\begin{tabular}{|c|c|c|c|c|c|c|c|c|}
\hline \multirow{2}{*}{ Soil samples } & \multicolumn{8}{|c|}{ Contamination factor ( $\mathrm{mg} / \mathrm{kg}$ ) } \\
\hline & Cd & $\mathrm{Cr}$ & $\mathrm{Cu}$ & $\mathbf{F e}$ & Mn & $\mathbf{N i}$ & $\mathbf{P b}$ & Zn \\
\hline Contaminated Soil & $8.45 \pm 1.42$ & $2.28 \pm 0.00$ & $2.52 \pm 1.00$ & $1.56 \pm 0.00$ & $1.09 \pm 0.18$ & $1.00 \pm 0.06$ & $1.49 \pm 0.11$ & $1.80 \pm 1.19$ \\
\hline
\end{tabular}

The results revealed that the translocation factors of all the metals in the plants tissues were greater than one except for $\mathrm{Cr}$ and $\mathrm{Ni}$ in Neem (Azadirachta indica) and Mn in Baobab (Adansonia digitata) (Table 3).

Table 3. Translocation of Metals $(\mathrm{mg} / \mathrm{kg}$ ) from Roots to Shoots of Plant Samples in Polluted Area.

\begin{tabular}{|c|c|c|c|c|c|c|c|c|}
\hline Plant Sample & Cd & $\mathrm{Cr}$ & $\mathbf{C u}$ & $\mathrm{Fe}$ & Mn & $\mathrm{Ni}$ & $\mathbf{P b}$ & Zn \\
\hline Jatropha & 1.86 & 1.64 & 1.09 & 1.04 & 1.15 & 1.15 & 3.03 & 1.00 \\
\hline Neem & 1.98 & 0.71 & 1.21 & 1.18 & 1.00 & 0.99 & 1.19 & 1.24 \\
\hline Baobab & 1.30 & 1.11 & 1.58 & 2.58 & 0.77 & 1.82 & 1.47 & 1.15 \\
\hline
\end{tabular}

These values indicated higher availability and distribution of metals in soils contaminated with heavy metals in the three plant species which can be labeled as translocators of $\mathrm{Cd}, \mathrm{Cr}$, $\mathrm{Cu}, \mathrm{Fe}, \mathrm{Mn}, \mathrm{Ni}, \mathrm{Pb}$ and $\mathrm{Zn}$ based on $\mathrm{TF}>1$. Heavy metal tolerance with high $\mathrm{TF}$ value have been suggested for phytoaccumulator of contaminated soils $[42,43]$ and therefore these plant species can be used as phytoremediators for multi-metal contaminated soils.

Also the results revealed high bioaccumulation factors (BAF) of all the metals examined in the tissues. All the BAF values were greater than one, except for $\mathrm{Zn}(0.96), \mathrm{Cd}(0.76)$ and $\mathrm{Ni}(0.84)$ in Jatropha (Jatropha curcas) leaves and stems respectively; $\mathrm{Cr}$ (0.90), Fe (0.96) and Zn (0.70) in leaves and $\mathrm{Cr}$ (0.63), Ni (0.89) and $\mathrm{Zn}(0.97)$ in stems of Neem (Azadirachta indica); Ni (0.99) and $\mathrm{Zn}(0.92)$ in the leaves of Baobab (Adansonia digitata) (Table 4). The bioaccumulation of the metals indicates a great performance of these plant species for metals phytoextraction and could be labeled as accumulator plants [44]. 
Table 4. Bioaccumulation Coefficient (BAC) Values for Heavy Metals in the Tissues of Plants.

\begin{tabular}{|c|c|c|c|c|c|c|c|c|c|}
\hline \multirow{2}{*}{ Plant } & \multirow{2}{*}{ Plant Parts } & \multicolumn{8}{|c|}{ Bioaccumulation Coefficient (BAC) } \\
\hline & & Cd & $\mathrm{Cr}$ & $\mathbf{C u}$ & $\mathbf{F e}$ & Mn & $\mathbf{N i}$ & $\mathbf{P b}$ & Zn \\
\hline \multirow{3}{*}{ Jatropha } & Leaves & 2.43 & 2.00 & 1.42 & 1.74 & 1.75 & 1.13 & 4.22 & 0.96 \\
\hline & Stems & 0.76 & 2.49 & 2.37 & 1.37 & 2.00 & 0.84 & 2.38 & 1.41 \\
\hline & Roots & 1.71 & 2.75 & 3.45 & 3.00 & 3.25 & 1.72 & 2.18 & 2.37 \\
\hline \multirow{3}{*}{ Neem } & Leaves & 3.09 & 0.90 & 2.10 & 0.96 & 3.33 & 1.34 & 2.77 & 0.70 \\
\hline & Stems & 1.79 & 0.63 & 3.04 & 1.64 & 2.33 & 0.89 & 2.31 & 0.97 \\
\hline & Roots & 2.45 & 2.23 & 4.27 & 2.20 & 5.67 & 2.24 & 4.26 & 1.35 \\
\hline \multirow{3}{*}{ Baobab } & Leaves & 2.09 & 1.97 & 1.29 & 2.52 & 1.11 & 0.99 & 1.73 & 0.92 \\
\hline & Stems & 1.09 & 1.65 & 1.75 & 1.06 & 1.11 & 1.75 & 1.90 & 1.11 \\
\hline & Roots & 2.47 & 3.28 & 1.93 & 1.39 & 2.89 & 1.51 & 2.48 & 1.76 \\
\hline
\end{tabular}

\section{Conclusion and Recommendations}

The results obtained showed that Jatropha (Jatropha curcas), Neem (Azadirachta indica) and Baobab (Adansonia digitata) can accumulate heavy metals from contaminated soils. The bioaccumulation and translocation factors were found to be greater than one except in few cases; indicating that all the three plant species are potentially useful for remediating heavy metals contaminated soils for these metals $(\mathrm{Cd}, \mathrm{Cr}, \mathrm{Cu}, \mathrm{Fe}, \mathrm{Mn}, \mathrm{Ni}, \mathrm{Pb}$ and $\mathrm{Zn})$. It is recommended that these plants: Jatropha (Jatropha curcas), Neem (Azadirachta indica) and Baobab (Adansonia digitata) can be ideal option for the phytoremediation in multi-heavy metal contaminated soils. These plants if massively planted in and around the industrial estate would reduce these metals in the soil and would also in the long run help to prevent the ground water contamination by heavy metals in the industrial effluents.

\section{References}

[1] Sadowskyy MJ (1999) In Phytoremediation: Past promises and future practices. Proceedings of the $8^{\text {th }}$ International symposium on Microbial Ecology. Halifex, Canada: 1-7.

[2] Henry JR (2000) In An Overview of phytoremediation of Lead and Mercury. NNEMS Reports, Washington DC: 3-9.

[3] Susarta S, Medina VF, McCutcheon SC (2008) Phytoremediation: An ecological solution to organic chemical contamination. Ecological Engineering 18(5): 647-658.

[4] Jadia CD, Fulekar MH (2009) Phytoremediation of heavy metals: Recent Techniques. African Journal 7(5): 547-558.

[5] Zhang BY, Zhen JS, Sharp RG (2010) Phytoremediation in engineered wetlands: Mechanism and applications. Procedia Environmental Science 2: 1315-1325.

[6] US-EPA (2001) Lead, identification of dangerous levels, final rule. Code of Fed. Reg., 66: 1206-1240.

[7] McNeil KR, Waring S (1992) In Contaminated land treatment technologies (ed. Rees J. F.). Society of Chemical Industry. Elsevier Applied Sciences: 143-159.

[8] Smith B (1993) Remediation updates funding the remedy. Waste Management Environment 4: 24-30.

[9] Williams GM (1998) Land disposal of hazardous waste. Engineering and Environmental Issues: 37-48.
[10] McBride HB (1994) Environmental chemistry of soils. Oxford University Press, New York.

[11] Alloway BJ, Jackson AP (1991) The behavior of heavy metals in sewage-sludge amended soils. Science Total Environment 100: 151-176.

[12] Khan AG (2005) Role of soil microbes in the rhizosphere of plant growing on trace metal contaminated soils in phytoremediation. Journal of Trace Element and Medical Biology 18: 3556-3564.

[13] Ward OP, Singh A (2004) Soil bioremediation and phytoremediation- An overview. In Applied bioremediation and phytoremediation 1: 1-11.

[14] Bichi MH, Anyata BU (1999) Industrial waste pollution in the Kano river basin. Environmental Management and Health 10 (2): 112-116.

[15] Akan JC, Moses EA, Ogugbuaja VO, Abah J (2007) Assessment of tannery industrial effluent from Kano metropolis, Kano State, Nigeria. Journal of Applied Sciences 7 (19): 2788-2793.

[16] WHO (1984) International standards for drinking water quality. World Health Organization, Geneva.

[17] Akan JC, Abdulrahman FI, Ogugbuaja VO, Reuben KD (2009) Study of the physico-chemical pollutants in Kano industrial areas, Kano State, Nigeria. Journal of Applied Sciences in Environmental Sanitation 4(2):89-102.

[18] Mu'azu AU, Kabir JA, Issa BR, Ndamitso MM (2010) Assessment of some heavy metals in lettuce, sesame and okra irrigation from Challawa River Kano, Nigeria. Oriental Journal of Chemistry 26(4): 1299-1308

[19] Gupta, S. Nayek, R. N. Saha and Satpti, S (2008) Assessment of heavy Metal accumulation in macrphyte, agricultural soil and crop plants adjacent to discharge zone of sponge iron factory. Environ. Geol., 55: 731-739

[20] Hakanson L (1980) An ecological risk index for aquatic pollution controls. A Sedimentological approach. Water Resources 14: 975-1001.

[21] Baker, AJM. Brooks RR (1989) Terrestrial higher plants which hyperaccumulate metallic element a review of their distribution, ecology and phytochemistry. Biorecovery $1: 81-126$

[22] Ma LQ, Komar KM, Tu C, Zhang W, Cai Y, Kanelly ED (2001) A Fern that hyper-accumulates arsenic. Nature 42(1): 291-301. 
[23] Zyad A, Gowthaman S, Terry N (1998) Phytoaccumulation of trace elements by wetland plants; Duckweed. Journal of Environmental Quality 27: 715-721

[24] Huang JW, Chen J, Berti WR, Cunningham SD (1997) Phytoremediation of lead-contaminated soil: role of synthetic chelaatesvin lead phytoextraction. Environ. Sci. Technol., 31:800-805

[25] Todorovic Z, Poli P, Djordjeri D, Antonijevi S (2001) Lead distribution in water and its association with sediment constituents of the "Barje" lake (Leskovac, Yugoslavia). Journal of the Serbian Chemical Society 66(10): 697-708.

[26] Nnaji JC, Omotugba S (2014) Physico-chemical quality of drinking water in New Bussa, Niger State, Nigeria. International Research Journal of Pure and Applied Chemistry 4(4): 437-446.

[27] Tuzen M (2003) Determination of heavy metals in soil, mushroom and plant samples by atomic absorption spectrometry. Microchemical Journal 74(3): 289-297.

[28] APHA, AWWA, WPCF (1985) Standard methods for the examination of water and wastewater. American Public Health Association, Washington DC.

[29] Awofolu OR (2005) A survey of trace metals in vegetation, soil and lower animals along some selected major roads in metropolitan city, Lagos. Environmental monitoring and assessment 105:431-449.

[30] US-EPA. Methods 3050, 7130, 7420 (1986) Test methods for evaluating solid waste. Laboratory manual-physical/chemical method SW-846, $3^{\text {rd }}$ Ed. Washington DC.

[31] Audu, A A and Lawal, A O (2006) Variation in metal contents of plants in vegetable Garden sites in Kano Metropolis. Appl. Sci. Environmental Mgt., 10 (2): 105-109

[32] Steel RCH, Dickey DA (1996) Principles and procedures of statistics. McGraw Hill, New York, USA: 234-256.

[33] Bowen HJM (1997) Environmental chemistry of elements. Academic Press Incorporation, London Ltd.:7.

[34] Awokunmi EE, Asaolu SS, Ipinmoroti KO (2010) Effect of leaching on heavy metal concentration of soil in some dumpsites. African Journal of Environmental Science and Technology 4(8): 495-499.
[35] ATSDR. Toxicological profile for Manganese (update) (2000) US Department of Health and Human Services, Public Health Service, Agency for Toxic Substance and Diseases.

[36] Malik RN, Hussein SZ, Nasir I (2010) Heavy metals contamination and accumulation in soil, wild plants species from industries area of Islamabad, Pakistan. Pakistan Journal of Botany 42 (1): 291-301.

[37] Qihang W, Wang S, Thangavel P, Qingfei L, Zheng H, Ju B, Qui R (2011) Phytostabilisation of Jatropha Curcas L. in polymetallic acid mine tailings. International Journal of phytoremediation 13: 788-804.

[38] Islam MM, Nik M, Majid M, Yamarnis R (2012) Heavy metal uptake and translocation by Jatropha Curcas L. in saw dust sludge contaminated soil. Australian Journal of crop Science AJCS6 (\%): 891-898.

[39] Barma SC, Sahu RK, Bhargava SK, Chatterjee C (2000) Distribution of heavy metals in wheat, mustard and weed grains irrigated with industrial effluents. Bull Environmental Contamination Toxicology 64: 489-496.

[40] Sun Y, Zhou Q, Wang L, Liu W (2009) Cadmium tolerance and accumulation characteristics of Bidens pilosa L. as a potential Cd-hyperaccumulator. Journal of Hazard Material 161 (23): 808-814.

[41] Lehoezky E, Szabo L, Horvath S (1998) Cadmium uptake by plants in different soils. Commun., Soil Sci. Plant Anal., 29: 1903-1912.

[42] Yoon J, Cao XD, Zhou QX, Ma LQ (2006) Accumulation of Pb, $\mathrm{Cu}$ and $\mathrm{Zn}$ in native plants growing on a contaminated Florida site. Science Total Environment 368: 456-484.

[43] Waziri M, Abdullahi U, Audu A A, Kalimullah (2016) Phytoremediation potentials of selected plants in industrially contaminated soils. International Journal of Environmental Science and Development 7 (10): 757-762.

[44] Scragg, A (2005) Environmental Biotechnology. Oxford University Press, New York: 31-45. 